\title{
Research of School Bullying Behaviors on Junior High School Students in Southern Taiwan City
}

\author{
Wang, Chuan-Hsing ${ }^{1}$, Chou, Mei-Ju ${ }^{2, *}$, Huang, Chia-Fen ${ }^{3}$ \\ ${ }^{1}$ Institute of Education, Taiwan Shoufu University, Taiwan \\ ${ }^{2}$ Department of Early Childhood Education and Center for Teacher Education, National Pingtung University, Taiwan \\ ${ }^{3}$ Sin-Tung Junior High School, Tainan City, Taiwan
}

Copyright $\mathrm{C} 2016$ by authors, all rights reserved. Authors agree that this article remains permanently open access under the terms of the Creative Commons Attribution License 4.0 International License

\begin{abstract}
The purpose of this study is to understand the current situation of the school bullying behaviors of students in junior high schools in Tainan City. It also compares the differences among the varied personal, family, and school

bullying. The facts include interpersonal relationship, homeroom teacher's misinterpretation, gender, the harmony of parents' marriage, family members, and parents' discipline.
\end{abstract} backgrounds, and explores the relationships between what influences school bullying and being-bullied behaviors and school bullying and being-bullied behaviors. Finally, it analyzes the anticipated facts that influence school bullying and being-bullied behaviors. The subjects in this research were the public and private junior high school students of seventh, eighth, and ninth grade in Tainan City, and the researcher compiled questionnaires -"the investigation on the school bullying behaviors of students in junior high school in Tainan City." There were 641 questionnaires given and 639 effective questionnaires were collected. The data was analyzed by using descriptive statistics, the method of Independent $t$ test, One-way ANOVA, Scheffe Posteriori comparison, Pearson Product-moment and multiple regression with SPSS. The findings were as follows: 1 . The school bullying behaviors on students of junior high school in Tainan City still exist. 2. There are significant distinctions on the school bullying behaviors in the different personal backgrounds for the students of junior high school in Tainan City, including gender, interpersonal relationship, and academic achievement. 3. There are significant distinctions on the school bullying behaviors in the different family backgrounds for the students of junior high school in Tainan City, including family members, sibling numbers, the harmony of parents' marriage, and parents' discipline. 4. There are significant distinctions in the school bullying behaviors in the different school backgrounds for the students of junior high school in Tainan City, including homeroom teacher's discipline. 5. The whole school bullying behaviors, bullying behaviors and being bullied of students of junior high school in Tainan City are positively related to each aspect - privacy, language, body, and majority. 6. There is significant anticipation of the facts of influencing school bullying behaviors for school bullying behaviors. That means we can use the facts of junior school bullying behaviors to predict the behaviors of school

Keywords Junior High School Student, Bully, Family Harmony, Teacher Discipline

\section{Research Background and Motivation}

School is supposed to be an environment where students can learn happily and parents do not have to worry about children's safety, but the fact is not as we have expected. The campus bullying behaviors, such as joking among classmates, verbal cursing, and bodily conflict, is a way for students to demonstrate their own power. Such attacking behaviors, in spite of being defined as students' "playing a trick" most of the time and tolerated or ignored by the adults, have caused tremendous trauma and become unforgettable shadow for the victim.

According to the survey of Child Welfare League Foundation in 2007 , there were around $60 \%$ of students in elementary school and junior high school that have been bullied. In other words, one has the experience of being bullied every two children, $2 \%$ of the students often bully their classmates, and $2 \%$ bully classmates every day (Wang, 2013)[1]. Some scholars analogue the bullying behaviors as weeds that grow flourishingly as long as we neglect them for a while (Siziya, Rudatsikira, \& Muula, 2012)[2], showing that bullying behaviors exist on campus prevalently. It is hard for the researcher, who has been working on the front line as an educator, to imagine, and thus wish to further understand the factors of bullying or bullied behaviors.

In recent years, a lot of bullying events exploded in school, which has made the researcher so astonished as to ask "does our society really learn a lesson from the bullying tragedy of the Grade-9 student Yeh Yung-chi in Kao Shu Junior High School in Ping Tung County in 2000?" (On April 20, 2000, the Grade-9 student Yeh Yung-chi in Kao Shu Junior High 
School told his teacher that he wanted to go to the toilet 5 minutes before the class ended, but he went without returning to class anymore. After class, it was found that he lied in blood. After investigation, it was found that Yeh Yung-chi dared not go to toilet in class break time because of his feminine characteristics--other boy students were always trying to take off his pants to check his gender, so that he always went to toilet before class time was over.) Nonetheless, there are still numerous bullying events left undiscovered. Take Taipei City as example, the survey in 2008 presented that a total of 3378 students claimed that they had ever been beat or extorted, although there were only 24 bullying events according to school's reports (Bollmer et al, 2006; Gini, 2006; Ttofi, \& Farrington, 2011)[3][4][5], which proves the severity of campus bullying events and the private property that makes them hard to be aware of.

In order to demonstrate the government's determination to anti-bully, Legislative Yuan passed "the Eight Amendment of Educational Fundamental Act" in October, 2011, adding the article that the government should protect the students from being invaded by the "bullying behaviors" when they receive education in school. The Legislative Yuan read the third times and passed the amended article that regulated that in addition to protecting students' learning right, education receiving right, body autonomy right, and personality development right, students should be free from any bodily punishment and bullying behaviors that damage their body and mind. Besides, in regard of the preventive mechanism, treating process, and other norms of bullying behaviors, the central authority educational administration organ is empowered to regulate the rules for enforcement (Berger, 2007; Georgiou, \& Stavrinides, 2013)[6][7].

Actually, school violence has always been existing on campus. Owing to school violence events getting increasingly common and worsening, it becomes the focus of Taiwan government and public (Carlyle \& Steinman, 2007)[8]. On the basis of Olweus, \& Limber (2010)[9] and Rigby (2008)[10], and River et al (2009)[11], school violence is getting everybody's attention, which involves ordinary time and place, brutal measures, and more and more teachers become the victims, showing people's neglect of moral norms and laws and regulations.

Research (Bender, \& Losel, 2011; Glew, Fan, Katon, \& Rivara, 2008; Nation, et al, 2008; Lund et al, 2009)[12][13][14][15] has pointed that from social learning theoretical perspective, imitation is the core for children to solve their socio-psychological crisis, since in living surroundings, children obtain most knowledge through observation and imitation of others, and the adults and society in turn provide modeling in children's daily life. By means of observing and imitating the adults, children learn the solution to problems. Research (Williams, \& Guerra, 2007; Due, \& Holstein, 2008; Allison et al, 2009)[16][18] proposes that a series of behaviors of walking over the weak on campus are a process and result of bullying from home, school, to the society in the future. That is to say, occurrence of school bullying is derived from the socialized occasion they contact earliest in their life--home. Most parents love their children and are patient with them. Unfortunately, some parents do not provide care they should do; some ignore their kids, and others even abuse them. Parents' educating patterns will have profound influence on children's development of body and mind, and even on their adaptation of life in the future as well as their violence attacking behaviors. (Kartal, \& Bilgin, 2009; Thornberg, 2011)[19][20] School is the second place for children to learn socialization, and class is the main field where children learn in school. Homeroom teacher is the core figure who operates class atmosphere, so his/her faith or leading methods will have an influence on students' behaviors and learning. Some homeroom teachers realize their influence and power over students, so they speak and act carefully. Contrarily, some homeroom teachers are so aware of their ultimate power that they maneuver power to intimidate students as the bullier. Authoritative and collectivized thinking methods result in human value distorted severely in the educational system (Beaty, \& Alexeyev, 2008).[21]

Occurrence of bullying may come from influence of varied factors, like heredity, environment, family, school, and etc. (Vanderbilt, \& Augustyn, 2011; Farrington \& Ttofi, 2009)[22]. Among those factors, some are "uneasy to change" like family environment, parents' marital relationship, and school system. Whether school bullying behaviors are influenced by family and school background or other factors, and what is the correlation among them is the second motivation of this research.

\section{Research Purpose and Questions to Be Answered}

In accordance with the research motivations above, the main purposes of this research are to understand the current conditions and distribution of students' bullying behaviors in junior high schools in Southern Taiwan Cities, and discuss influence of different background variables on school bullying. Lastly, on the basis of research results, we provide reference to parental personnel, educators, and relative units and personnel to deal with school bullying events, and prevent bullying events from taking place. The research purposes are listed below:

\section{(I). Research Purposes}

1. Understand the current conditions and distribution of students' bullying behaviors in junior high schools in Southern Taiwan Cities

2. Discuss differences between the personal background variables and school bullying behaviors students in junior high schools in Southern Taiwan Cities

3. Discuss differences between the family background and school bullying behaviors students in junior high schools in Southern Taiwan Cities

4. Discuss differences between the school background and school bullying behaviors students in junior high schools in Southern Taiwan Cities 
5. Discuss Southern Taiwan City's junior high schools students' predictive power for factors that influence on school bullying behaviors

6. In accordance with research findings and results, we propose relative suggestions for relative units and personnel who handle school bullying events and prevent such events from happening.

7. By generalizing the research results, we provide parents and educators reference data and expect that it is helpful for handling and preventing school bullying events.

\section{(II). Questions to Be Answered}

According to the purposes of this research, we further develop relative questions to be answered, as listed below:

1. What are the current condition and distribution of students' bullying behaviors in junior high schools in Southern Taiwan Cities?

2. Do students' bullying behaviors in junior high schools in Southern Taiwan Cities

differ as students' personal background variables vary?

3. Do students' bullying behaviors in junior high schools in Southern Taiwan Cities

differ as students' family background variables vary?

4. Do students' bullying behaviors in junior high schools in Southern Taiwan Cities

differ as students' school background variables vary?

5. How is Southern Taiwan City's junior high schools students' predictive power for factors that influence on school bullying behaviors?

\section{Literature Discussion}

Education is engineering of mankind's hope, and school is the cradle of students' learning and growth as well as the field of hope engineering. Students spend one third of daily time in school, so establishing a warm, friendly, and safe environment is required (Marsh et al, 2010; Juvonen, \& Gross, 2008; Vaillancourt et al, 2010)[24][25][26]. With information of violence flooding, children learn distorted values unconsciously after situated in such environment. In addition, as age swifts fast and family becomes unbalanced, children resort to violence as soon as they encounter problems, making campus filled with uneasy elements (Lindsay, \& McPherson, 2012; Petrosino et al, 2010)[27][28].

\section{(I). Definition of Bullying}

Bullying behaviors can be dated back a long time ago. In earlier stage, such behaviors were called "pick on" or "walk all over" someone. In recent years, the education circle in Taiwan began to propose the verb "bully". Research (Bradshar, \& Waasdorp, 2009; Ramya, \& Kulkarni, 2011; Swearer et al, 2010)[29][30][31] defines bullied as a student's exposure to being picked on or disturbed by one or more students repeatedly for a long time, or a student's being targeted as the bullied object. Research (Farrow, \& Fox, 2011; Mehta et al, 2013) [32][33]also indicates that "bully" refers to children's unequal pressing and picking on--that is, to walk all over others maliciously. These tyrannizing behaviors among peers may include bodily or verbal attacks, and may involve with talking about something like sexual harassment or sarcasm, comment, or ridicule at part of body, which will have negative influence on mental and physical effect as time passes. Bullying refers to someone powerful than oneself conducts harmful and purposeful behaviors repeatedly that harm the victim mentally and physically (Pergolizzi et al, 2009; Roth et al, 2011)[34][35]. Ministry of Education of Taiwan has defined campus violence in broad and narrow sense. In a narrow sense, it means the behaviors among students, teacher and students, parents and students, the intruder off-campus and teacher/students that damage life and body. In other words, it refers to the criminal behavior using rape, threaten, or other measures to oppress the victim's resistant capability and intention in order to complete particular illegal intention. In a broad sense, in addition to the above-mentioned, it also refers to the student's behaviors of harming his/her own life and body, like self-damage and suicide.

To sum up, in this research, bullying is defined as a phenomena of unbalanced power among children, and it a long-term and repeated private bullying, gridding bullying, bodily bullying, and unified bullying that causes the individual's physical or psychological harm.

\section{(II). Types of Bullying}

School bullying is represented in diverse forms. Schneider et al (2012) [36]classifies bullying behaviors into two aspects--"direct/indirect" and "physical/mental". So-called direct bullying is to attack the victim apparently and publicly through verbal, bodily, positioning, extorting, and cyber bullying, while indirect bullying proceeds attacks through invisible measures hard to get aware of-- by means of one's power in the group relationship (Bull, \& cheithauer, 2009; Viding et al, 2011 ).[37][38]

In addition, with the rapid advancement of technology, some scholars even proposed the concept of cyber bullying. As Olweus (2013)[39] indicates, cyber bullying refers to utilizing platforms like cyber-space (instant messages, smart phone, e-mail, BBS, blogs, chat-room, message board, and so on) to send or post messages or articles that make people feel embarrassed, mock at people, or insult people, so that such messages/articles are circulating extensively among peers or unknown public. In other words, it attempts to take advantage of public trial of e-punishment and the undetectable message source to make the victim feel terrified and harassed so that the purpose of harming the victim can be fulfilled. As the international market survey institution Ipsos Social Research Inst announced, Australian students suffer severely from cyber bullying. 9 from 10 pairs of parents expressed that their kids or kids of their acquaintances have experienced cyber bullying.

Bodily bullying is more apparent, and can be seen and detected immediately. In contrast, verbal, psychological, or sexual bullying is less apparent and indirect; and will only be 
perceived through careful and long-term observation or being told by the bully. Many studies have found that the most common and deeply sensed bullying is primarily verbal, because verbal bullying may take place in a jiffy, and it is of privacy, hard to be detected by the adult, so the occurrence rate is high (Farrington, \& Ttofi, 2009)[23].

Currently, complicated society and distorted values raise occurrence rate and the damage extent of various types of bullying behaviors, resulting in the once simple, secure campus encountering the unprecedented impact. Consequently, teachers and students in school and parents' in the family must have more understanding of types and influence of bullying.

On the basis of bullying types, Child Welfare League Foundation categorizes bullying into 5 types: bodily, verbal, relational, attacking, and sexual bullying. Moreover, Swearer et al (2010)[31] propose the concept of cyber bullying, indicating that cyber bullying applies cyber space platform to send or post what embarrasses, mocks at, and insults people, or unbearable gossips and images. In this research, our questionnaire extracts the content of Child Welfare League Foundation's and Chu Mei-guei's proposals, and makes further exploration on the four types of school bullying and the conditions of the bullied in junior high schools in Southern Taiwan Cities: the bully and the bullied of privacy, mock, body, and unity.

\section{(III) The Inter-relational Party of School Bullying}

In Swearer et al (2010)[31], dramatic approach is employed to deal with school bullying and conflict, and the inter-relational parties in bullying behaviors are designed as follows:

1. The bullied: the victim(s) who is (are) oppressed or abused violently in special situation.

2. The bully: In particular situation, those who abuses power to oppress the weaker systematically.

3. The Bystanders: In particular situation, those to allow or encourage bullying event, even if they are only watching, they are considered as accomplices as well.

In addition, the roles in cartoon Doraemon are highly correlative to school bullying, as what goes in the following (quoted from Child Welfare League Foundation, 2007):

1. The bully: In school or peer group, one who ceaselessly harms, menaces, threatens, or pushes aside classmate(s).

2. The targeted children: the bullied object, some are even bullied on a long-term basis, which has negative influence on mental and physical health and development.

3. The bystanders: Anyone that knows bullying is happening. Some bystanders even actively push the bully to proceed harmful actions.

The above descriptions of bullying behaviors analogue the favorite Cartoon Doraemon to arouse children's sympathetic feelings and help them clarify the role of the bully, the bullied, and the bystanders.

\section{(IV). Bullying Behavior Related Theories}

From bullying behavior related studies, it can be found that students' bullying behaviors relate to instinct of aggression, frustration-aggression theory, social learning theory, differential association theory, social control theory, dominance theory, spiritual skill theory, which are discussed below:

\section{Theory of Instinct of Aggression}

Freud's psycho-analysis regards that people has two instincts-- one is the life instinct that maintains the individual life and reproduction of race multiplication, and the other is the death instinct. Two instincts are antagonistic. Presentation of the attacking instinct is a kind of expression of the death instinct. Additionally, Freud divided personality structure into id, ego, and super-ego, among which id is where the personality full of instincts, desires, and energy, and is born by nature. At this point, all mankind have attacking instinct that is very evident and universal since infant and child stage. For example, the infant kicks and hits mother since he/she is little, and demonstrates attacking behaviors like squeezing and biting. When he/she is a little bigger, he/she criticizes others' body shape, appearance, hair, and dressings. Then, in adolescence, he/she mocks at the sexual traits of the opposite sex. All those behaviors have never been defined as bullying; however, the attacking implication is obvious, simply owing to attacking can satisfy man's basic needs.

Besides, Norris and Gray think that all men are inclined to attacking drive, which is the primary factor leading to individual's committing a crime. How strong or weak of one's attacking drive differs with varied heredity and environment, and shapes divergent crime motivations. People with strong drive tend to have higher crime rate than those with weak drive (Jimerson, Swearer, \& Espelage, 2010)[40][2]. Consequently, in Siziya, Rudatsikira, \& Muula 2012) research, it pointed out that when the bully describes the bullying behaviors, he less blames himself/herself, and even obviously shows pleasure, implying that in facing bullying behaviors, the bully seldom feels guilty, and does not regret for the harm he/she has caused, even feels good in the bullying process.

Students' bullying behaviors are a kind of pattern, and those visible or invisible bullying behaviors may be attacking behaviors by instinct. From the above-mentioned, it is learned that for the bully, bullying behaviors may be particular pursuit of one's instinct. Even if this is true, it does not mean that bullying behaviors can be justified; in contrast, it signifies the importance of education and law.

\section{Frustration-Aggression Theory}

In frustration-aggression theory in psychology, any frustration events may trigger attacks. As Miller considers, attacking behaviors are deemed to be caused by frustration, although frustration does not always cause attacking behaviors. People have a lot of reactions to frustration, including sense of inferiority, helplessness, crying, complaint, attacks, and so on (Viding et al, 2011).

Berkowitz proposes "cue arousal theory" that holds: 
Frustration is merely a kind of psychological feelings, which will not be directed to specific reaction form if no guiding cues in the environment are provided. If the individual finds any cues of attack in the environment, he/she may conduct attacking behaviors. However, if the cues suggest that the attacking behaviors will not be allowed by the society, the individual would inhibit the attacking behaviors.

Also, bullying behaviors are a kind of methods for mankind's attacking behaviors, which may be caused by frustrations such as poor performance at school, poor interpersonal interaction, and etc., all leading to bullying behaviors. In fact, those attacking behaviors may not occur if they are restricted by the regulations in the surroundings or if there are no incentives (like acquirement of power). Nonetheless, occurrence of bullying behaviors often relates to strong or weak power demonstration, and such incentive is irresistible for the quick-tempered junior high school students. Besides, the forms of bullying behaviors are varied, and many cannot be aware of easily, so they cannot be controlled. That is to say, in encountering frustrations, junior high school students tend to bully others in the form of attack, which is quite popular nowadays in Taiwan.

\section{Social Learning Theory}

Social learning theory, an argument under behaviorism, is promoted by Albert Bandura. He proposes that man's learning is different from the animals, that mankind can generate learning behaviors through observing others' behaviors, unlike what Burrhus F. Skinner's behaviorism claims that all are learned through external and evident contact experience. As a result, Burrhus is called the modifier of extreme behaviorism in psychology (Rivers, \& Noret, 2013)[11]. Social learning theory holds that the individual can learn from others' behaviors in the social situation, so it emphasizes modeling and imitation, like the meaning of "learning from the good in others" and "unconscious cultivation".

In Bandura's perspective, people are not born with instinct of violent behaviors; rather, it is learned by living experiences, such as observing others' making use of attacking behaviors to carry out goals, or observing others benefiting from violent behaviors through media--all may enable the observer to learn such violent behaviors (Mehta et al, 2013)[33]. The most representative is the Bobo doll experiment in 1960s, which aimed to explain that contacting the behavioral model with violence-tendency may arouse imitating effect for children to learn such violent behaviors. Just as news reported once that the rebellious child imitated the movie plot to kill his father because of getting angry at the father's blame. Consequently, if children observe that the adults are not punished for their violent behaviors, they will solve problems with violence in the future. Contrarily, if they observe the adults are punished for their violence, the occurrence of using violence to solve problems will be less.

In social learning theory, bullying behaviors are generated from learning, just like other behaviors. Bandura asserts that the individual's behaviors are the outcomes of interaction between the individual and the environment. In the process of learning behaviors, whether there will be attacking behaviors relies on the individual's punishment and award, self-control, prediction for the outcomes of behaviors, and identification with the external imitation. In the process of learning, if all those four experiences are beneficial to attacking behaviors, the individual will generate attacking behaviors (Atik, 2011)[42].

\section{Differential Association Theory}

Differential association theory was proposed by Sutherland, Edwin H in his book Principles of Criminology in 1939 to interpret crimes and deviation behaviors, claiming that people have different definitions of crime due to situated in divergent areas or social environments. In addition, acquirement of crime behaviors, motivation, and skills is a process of learning obtained during the non-criminal's contacting with the criminal (Bosiakoh, 2012; Moon, Hwang, $\&$ McCluskey, 2008)[43]. The more often the non-criminal getting in touch with the criminal, the more he/she will tend to commit a crime. Differential association theory is the same with social learning theory in the way that it highlights the individual's behaviors are learned from social interaction instead of being born by nature. Link (2014)[45] proposed what proposed by Thornberry et al in 1994 that there are three elements in differential association theory: Socialization, selection theory, and inter-influence theory of criminal peers. It means that only with the existence of environment for learning crimes, the criminal peers, and enhancement for committing a crime, regardless of award or encouragement, will the criminal's crime behaviors be generated. As for Sutherland, he lists the following nine points for the theory: 1 . crime behaviors are learned; 2 . crime behaviors are generated through learning in process of interacting and communicating with others; 3 . learning of crime behaviors mainly comes from group closer to the individual; 4. crime behavior learning includes crime skills, motivation, justified techniques, and attitudes; 5 . how much one learns about the definitions of law and what is beneficial or not beneficial to crimes will influence crime motivation and drive; 6 . why one becomes a criminal lies in his/her contact definition of what is beneficial to crime more than what is NOT beneficial to crime; 7. differential association theory differs with different frequencies, duration, priority, and intensity; 8 . the learning mechanism of crime behaviors is not different from that of other behaviors; 9. although crime behavior can interpret general needs and values, it fail to interpret crime behaviors with those needs and values.

The researcher has been serving in the junior high school, and she has found that peers have a remarkable influence on youngsters. She often sees students' changes in behaviors due to failure in making friends with different characters, and believes that this must also be what the parents worry and care the most, as well as what the school and teachers should pay attention to particularly.

\section{Social Control Theory}

In social control theory, bullying behaviors are resulted from the individual's weak connective relationship with the 
society, which is consistent with Hirschi's assertion that when the individual's social connective power weakens, the society's power of controlling its members will decrease, and crimes take place subsequently. Hirschi proposed four connective elements: commitment, involvement, belief, and attachment (Black, 2014)[46].

From the angle of attachment, if the individual values other people's expectation and viewpoints, it will be less possible for him/her to conduct deviation behaviors. Therefore, on the basis of theory, bullying behaviors may be relative to slight attachment extent with the important others in the family or school, like parents, teachers, peers, or the school's administrative institute. If the individual does not care the opinions of others in his/her surrounding, and is unwilling to coordinate with them, bullying behaviors will occur more easily. In this sense, strengthening the student-school and student-society connective power and cultivating good interpersonal interaction on campus will reduce the occurrence of bullying behaviors.

\section{Dominance Theory}

For boys, occupying dominant or superior position among peers is very important, particularly when they transfer to the new classroom or school (Rosenthal, \& Levy, 2010). As a result, the bully attack weaker peers in order to obtain resource or social position. Especially, when the bullied show sign of succumbing, their motivation to bully is even intensified. In the meantime, when the bully imposes pain on their peer, and such pain is clear and evident for the bully and his peer, such behavior will be intensified as well.

In addition, Gini (2006) also indicates that other than group identification and peer acceptance, social power and group position are also one of the channels for youngsters to raise their social position with the purpose to heighten self-esteem and obtain dominant position among their peers. Some individual or group takes aggressive behaviors towards the weaker peers just because it is an effective way to acquire social power. In accordance with Sidanius, \& Pratto, (2011)[48] study, such situation is more common in the transition of elementary school to junior high school.

Additionally, there are also studies showing that the bully has strong desire for dominating and controlling others, and such desire for dominance or control will often be intensified by the society, such as media's negative propaganda on violence when the public do not blame or inhibit it correspondingly. On the other side, students' obtaining dominant position in school is also a kind of social rewards for bullying.

\section{Spiritual Skill Theory}

The bully may be the central head with higher position and more power in the peer group, which implying that the bully has more influential power over others in the group. As socio-psychologists hold, people need to interact with others. If they are deprived of the opportunity to interact and contact with others, it will do harm on their spiritual development. Consequently, in order to possess the sense of belonging to the group, they produce horror of being pushed aside and isolated, and are eager to be included into the group (Corey, 2011)[49]. At this point, the bully control the group by means of the above-mentioned two affections, and form the bullying behaviors among peers.

Elias, Krauss, \& Aishah (2010)[50] revealed that most bullying events are caused by skillful bullies to employ group attack upon the victim by means of the group lacking aggregative power. As for the reason why we fix at specific group lacking aggregative power, it lies in bullying would allow the individual in the group feels that attacking the bullied makes him/her melting into the group more, his/her position can be raised, and this can even be regarded as a fashion. Under such premise, generally speaking, it is easier to maneuver friendship with low quality, because attacking the victim makes people have common goal and demonstrate aggregative power. And, such bullies can hide behind the group to proceed invisible attacks by way of maneuver (not just limited to indirect bullying), making the victim have no idea that who's operating the bullying event. The result is that the bullied tends to blame himself/herself when oppressed by the group's collective bullying behaviors.

As a whole, all the above-mentioned theories deducted the causes of bullying behaviors. This research mainly applies to social learning theory, because for the junior high school students, learning is made through observation and imitation from parents, teachers, peers, TV programs, Internet, and so on. If attacking events on campus or contacting with violence-related $\mathrm{TV}$ programs and Internet frequently, together with junior high school students' insufficient self-control and judging ability, and high sense of identification with their peers, the occurrence rate of junior high school students' bullying behaviors will increase. To sum up, if we want to prevent students from learning and imitating bullying behaviors, both teachers and parents should pay more attention to the children's learning environment.

\section{Research Methods and Design}

\section{(I). Research Subject and Sample}

This research was conducted with public and private junior high schools in southern Taiwan cities. Based on the basic data of public and private junior high schools from Bureau of Education in Southern Taiwan Cities in 2012 as the sampling foundation, the scale of schools was categorized into large, medium, and small schools. Among them, schools with more than 36 classes are large schools, totally 25 schools; $13-35$ classes are medium schools, totally 25 schools; and less than 12 classes are small schools, totally 27 schools. There are 746 grade seventh classes, 703 grade eighth classes, and 729 grade ninth classes, and the total number of students is 46064 . In this research, according to the public and private schools and the school scale, we conducted stratified random sampling, 641 students were 
sampled, and the population and sample distribution are presented in Table 1.

\section{(II). Research Tools}

This research used questionnaire as the tool to collect research data. After synthesizing relative literature, the researcher consolidated the research tool, "Questionnaire Survey on Bullying Behavior of Junior High School Student in Southern Taiwan Cities", and selected "Personal Basic Information", "Family Background", "School Background", and "School Bullying Behavior Scale" to carry out analysis.

\section{Professional Content Validity}

In order to strengthen the logic thoughtfulness, we invited professional scholars to proceed expert's viewpoint survey in order to modify the improper items and semantics. Them, the items were filtered based on the opinions provided by the experts, and integrated the opinions into the pre-test questionnaire after reviewed by the experts. After pretest, we collected the returned questionnaires for item analysis, and consolidated the formal questionnaire, "Questionnaire Survey on Bullying Behavior of Junior High School Student in Southern Taiwan Cities".

In the process of consolidating this questionnaire, various kinds of related literature and appropriate questionnaires or scales were collected. During this period, we discussed with the professional scholars, officials in Bureau of Education, school administration personnel, and teachers before consolidating the content validity questionnaire, where a blank field is left for the professional modification and suggestions. In order to ascertain the coverage, appropriateness, urgency, and correctness, in October, 2012, we invited educational professional scholars and principals in junior high schools, totally 6 experts, to review, modify, and make suggestions for the questionnaire with target at the content to serve as the basis of making the formal questionnaire.

This content validity questionnaire has been reviewed by the professional experts and the practitioners for suggestions on modification. According to frequency distribution and percentage method, we selected those with "proper" percentage over $80 \%$ to plus the proportion of "proper after modification", and preserved those with value higher than $90 \%$, and deleted those less than $90 \%$. That is, if the item was checked by five experts as "proper", we preserved it; if the item was checked by four experts as "proper" and tow as "proper after modification", we preserved it as well. But, we deleted the item if it was checked by four experts as "proper" and others as "improper", or checked as "improper" by more than two experts. Subject to professional opinions, the items were modified and preserved. Up to then current, the pre-test questionnaire was completed.
Table 1. Sampling

\begin{tabular}{|c|c|c|c|}
\hline $\begin{array}{c}\text { 101 Academic } \\
\text { Year }\end{array}$ & $\begin{array}{c}\text { Grade } \\
\text { Total classes }\end{array}$ & $\begin{array}{c}\text { Total } \\
\text { classes }\end{array}$ & $\begin{array}{c}\text { Expected sampling } \\
\text { number }\end{array}$ \\
\hline \multirow{4}{*}{ Public } & Grade-7 & & \\
& 649 & & \\
& Grade-8 & \multirow{2}{*}{1890} & 560 人 \\
\cline { 2 - 2 } & 607 & & \\
\cline { 2 - 2 } & Grade-9 & & \\
\hline \multirow{4}{*}{ Private } & 634 & & \multirow{2}{*}{ Grade-7 } \\
& 97 & \multirow{2}{*}{288} & \\
\cline { 2 - 2 } & Grade-8 & & \\
& 96 & & \\
\cline { 2 - 2 } & Grade-9 & & \\
\hline
\end{tabular}

Note: data source is derived from the Educational Network Center's Report Statistic Data in Tainan City

\section{Validity Construction}

Factor analysis of the formal questionnaire in this research is presented as two parts-- the factor analysis results of bullying behaviors and the factor analysis results of bullied behaviors.

\section{(1). The Factor Analysis Results of Bullying Behaviors in School Bullying Behavior Scale}

"Scale of School Bullying Behaviors--the Formal Questionnaire of Factors in Bullying Behaviors" includes four factors: "Private Bullying", "Mocking Bullying", "Bodily Bullying", and "United Bullying", as shown in Table 2.

Table 2. Factor Analysis Results of Formal Questionnaire of Scale of Bullying Behaviors in School Bullying

\begin{tabular}{|c|c|c|c|c|}
\hline \multirow{2}{*}{ Item No. } & \multicolumn{4}{|c|}{ Factor } \\
\cline { 2 - 5 } & $\begin{array}{c}\text { 1. Private } \\
\text { Bullying }\end{array}$ & $\begin{array}{c}\text { 2. Mocking } \\
\text { Bullying }\end{array}$ & $\begin{array}{c}\text { 3. Bodily } \\
\text { Bullying }\end{array}$ & $\begin{array}{c}\text { 4. United } \\
\text { Bullying }\end{array}$ \\
\hline a18 & .767 & -.120 & .297 & -.251 \\
\hline a13 & .763 & .220 & .359 & -.356 \\
\hline a19 & .750 & -.045 & .370 & -.416 \\
\hline a15 & .713 & .351 & .236 & -.039 \\
\hline a08 & .556 & .273 & .522 & -.401 \\
\hline a07 & .370 & .770 & .374 & -.315 \\
\hline a06 & .368 & .753 & .347 & -.375 \\
\hline a05 & .327 & .595 & .501 & -.417 \\
\hline a17 & .666 & .512 & .291 & -.421 \\
\hline a14 & .749 & .430 & .248 & -.414 \\
\hline a02 & .243 & .317 & .842 & -.129 \\
\hline a03 & .252 & .317 & .791 & -.168 \\
\hline a01 & .240 & .701 & .463 & -.065 \\
\hline a11 & .406 & .068 & .297 & -.786 \\
\hline a10 & .335 & .405 & .152 & -.759 \\
\hline a09 & .445 & .391 & .585 & -.644 \\
\hline a04 & .434 & .167 & .697 & -.506 \\
\hline a16 & .748 & .272 & .270 & -.492 \\
\hline a12 & .663 & .250 & .171 & -.334 \\
\hline
\end{tabular}




\section{(2) Factor Analysis Results of Formal Questionnaire of Scale of Bullied Behaviors in School Bullying}

"Factor Analysis of Formal Questionnaire of Scale of Bullied Behaviors in School Bullying" were divided into four factors--"Bodily Bullied", "Mocking Bullied", "United Bullied", and "Private Bullied", as shown in Table 3.

Table 3. Factor Analysis Results of Formal Questionnaire of Scale of Bullied Behaviors in School Bullying

\begin{tabular}{|c|c|c|c|c|}
\hline \multirow{2}{*}{ Item No. } & \multicolumn{4}{|c|}{ Factors } \\
\hline & 1. Bodily Bullied & 2. Mocking Bullied & 3. United Bullied & 4. Private Bullied \\
\hline b04 & .875 & .321 & -.182 & .408 \\
\hline b03 & .768 & .590 & .000 & .292 \\
\hline b02 & .649 & .223 & -.156 & .324 \\
\hline b01 & .364 & .744 & -.010 & .336 \\
\hline b07 & .337 & .856 & -.307 & .305 \\
\hline b06 & .284 & .811 & -.178 & .295 \\
\hline b05 & .444 & .728 & -.179 & .244 \\
\hline b09 & .561 & .608 & -.400 & .386 \\
\hline b17 & .361 & .481 & -.148 & .821 \\
\hline b10 & .415 & .510 & -.744 & .346 \\
\hline b12 & .367 & .370 & -.678 & .494 \\
\hline b11 & .644 & .346 & -.646 & .426 \\
\hline b16 & .418 & .234 & -.411 & .847 \\
\hline b18 & .541 & .195 & -.100 & .811 \\
\hline b19 & .828 & .220 & -.213 & .590 \\
\hline b14 & .536 & .398 & -.024 & .539 \\
\hline b13 & .745 & .481 & -.117 & .451 \\
\hline b15 & .482 & .494 & .263 & .448 \\
\hline b08 & .576 & .381 & -.273 & .365 \\
\hline
\end{tabular}

\section{Reliability Analysis}

After factor analysis of the formal questionnaire, reliability analysis was proceeded for each dimension, each construct, and the scale. The coefficient Cronbach $\alpha$ was used to examine the internal consistency. The higher the coefficient $\alpha$, the higher the reliability will be. In Table 3.19, the coefficient Cronbacharanges between .677-.812, and the Cronbach $\alpha$ value of the two constructs are .899 and .911 , both within the ideal range. The coefficient of the scale is .939 , showing that this scale has good internal consistent reliability, as Table 4 presents.

Table 4. Reliability Analysis of Formal Questionnaire on School Bullying Behavior Scale $N=639$

\begin{tabular}{|c|c|c|c|c|c|c|c|c|c|c|}
\hline Construct & Dimension & \multicolumn{6}{|c|}{ Item No. in Formal Questionnaire } & $\begin{array}{l}\text { Dimension } \\
\text { Reliability }\end{array}$ & $\begin{array}{l}\text { Construct } \\
\text { Reliability }\end{array}$ & aValue \\
\hline \multirow{4}{*}{$\begin{array}{c}\text { Bullying } \\
\text { behaviors }\end{array}$} & Private Bullying & 8 & 13 & 15 & 18 & 19 & & .791 & \multirow{4}{*}{.899} & \multirow{8}{*}{.939} \\
\hline & Mocking Bullying & 5 & 6 & 7 & 14 & 17 & & .811 & & \\
\hline & Bodily Bullying & 1 & 2 & 3 & & & & .677 & & \\
\hline & United Bullying & 4 & 9 & 10 & 11 & 12 & 16 & .785 & & \\
\hline \multirow{4}{*}{$\begin{array}{c}\text { Bullied } \\
\text { Behaviors }\end{array}$} & Private Bullied & 8 & 13 & 14 & 15 & 18 & 19 & .788 & \multirow{4}{*}{.911} & \\
\hline & Mocking Bullied & 5 & 6 & 7 & 9 & 17 & & .810 & & \\
\hline & Bodily Bullied & 1 & 2 & 3 & 4 & & & .731 & & \\
\hline & United Bullied & 10 & 11 & 12 & 16 & & & .812 & & \\
\hline
\end{tabular}




\section{Research Results and Discussion}

In this research, a total of 639 effective questionnaires were returned and analyzed statistically with SPSS for Windows 17.0 to discuss the current condition of bullying behaviors of students in junior high schools in Southern Taiwan cities, and the results are summarized and generalized as below:

\section{(I). The Overall Current Condition of Bullying Behaviors of Students in Junior High Schools in Southern Taiwan Cities}

Table 5. Summary of Bullying Behaviors of Students in Junior High Schools in Southern Taiwan Cities

\begin{tabular}{|c|c|c|}
\hline Item & Mean & Sequence \\
\hline Full Scale & 1.23 & I. \\
\hline Bullying Behavior & 1.25 & 1 \\
\hline Private Bullying & 1.12 & 2 \\
\hline Mocking Bullying & 1.48 & 3 \\
\hline Bodily Bullying & 1.21 & II. \\
\hline United Bullying & 1.19 & 4 \\
\hline Bullied Behaviors & 1.21 & 1 \\
\hline Private Bullied & 1.13 & 3 \\
\hline Mocking Bullied & 1.35 & 2 \\
\hline Bodily Bullied & 1.17 & 1.20 \\
\hline United Bullied & & 2 \\
\hline
\end{tabular}

From Table 5, it can be learned that:

1. The mean of school bullying behaviors of students in junior high school in Southern Taiwan cities (full scale) is 1.23.

2. For the two constructs, the mean of bullying behaviors is 1.25 , and that of the bullied behaviors is 1.21 .

3 . For the four dimensions of bullying behaviors, the mean of private bullying is 1.12 , that of mocking bullying is 1.48 , that of bodily bullying is 1.21 , and that of united bullying is 1.19 . In regard of the mean of bullying behaviors, the highest mean of mocking bullying is (1.48), and the lowest is private bullying (1.12).

4. For the four dimensions of bullied behaviors, the mean of private bullied is 1.13 , that of mocking bullied is 1.35 , that of bodily bullied is 1.17 , and that of united bullied is 1.20 . Consequently, in regard of the mean of bullied behaviors, the highest mean of mocking bullied is (1.35), and the lowest is private bullied (1.13).

(II). Relationship of Different Variables and Bullying Behaviors of Students in Junior High Schools in Southern Taiwan Cities 
Table 6. The Relative Relationship between Students with Different Background in respect with the Two Constructs and Each Dimension and their School Bullying Behaviors in Southern Taiwan Cities

\begin{tabular}{|c|c|c|c|c|c|c|c|c|c|c|c|c|c|}
\hline \multirow{2}{*}{\multicolumn{4}{|c|}{ (Sequence according to the Means) }} & \multirow[b]{2}{*}{$\begin{array}{c}\text { Bullying } \\
\text { Behaviors } \\
\text { (1) }\end{array}$} & \multirow[b]{2}{*}{$\begin{array}{l}\text { Bullied } \\
\text { Behaviors } \\
\text { (2) }\end{array}$} & \multicolumn{4}{|c|}{ Bullying Behaviors } & \multicolumn{4}{|c|}{ Bullied Behaviors } \\
\hline & & & & & & $\begin{array}{c}\text { Private } \\
\text { Bullying } \\
(1)\end{array}$ & $\begin{array}{c}\text { Mocking } \\
\text { Bullying } \\
(2)\end{array}$ & $\begin{array}{c}\text { Bodily } \\
\text { Bullying } \\
(3)\end{array}$ & $\begin{array}{c}\text { United } \\
\text { Bullying } \\
(4)\end{array}$ & $\begin{array}{c}\text { Private } \\
\text { Bullied } \\
(1)\end{array}$ & $\begin{array}{c}\text { Mocking } \\
\text { Bullied } \\
\text { (2) }\end{array}$ & $\begin{array}{c}\text { Bodily } \\
\text { Bullied } \\
(3)\end{array}$ & $\begin{array}{c}\text { United } \\
\text { Bullied } \\
(4) \\
\end{array}$ \\
\hline \multirow{13}{*}{$\begin{array}{c}\text { Personal } \\
\text { Background } \\
\text { Variables }\end{array}$} & & \multirow{3}{*}{ Grade } & Grade-7 & \multicolumn{2}{|c|}{$1>2$} & \multicolumn{4}{|c|}{$2>4>1>3$} & \multicolumn{4}{|c|}{$2>4>1>3$} \\
\hline & & & Grade- 8 & \multicolumn{2}{|c|}{$1>2$} & \multicolumn{4}{|c|}{$2>3>4>1$} & \multicolumn{4}{|c|}{$2>4>3>1$} \\
\hline & & & Grade- 9 & & & \multicolumn{4}{|c|}{$2>3>4>1$} & \multicolumn{4}{|c|}{$2>3>4>1$} \\
\hline & & \multirow{2}{*}{ Gender } & Male & & & \multicolumn{4}{|c|}{$2>3>4>1$} & \multicolumn{4}{|c|}{$2>3>4>1$} \\
\hline & & & Female & & & \multicolumn{4}{|c|}{$2>4>3>1$} & \multicolumn{4}{|c|}{$2>4>3>1$} \\
\hline & & \multirow{3}{*}{$\begin{array}{c}\text { Human } \\
\text { Relationship }\end{array}$} & $\begin{array}{c}\text { Get along well with most } \\
\text { classmates }\end{array}$ & & & \multicolumn{4}{|c|}{$2>3>4>1$} & \multicolumn{4}{|c|}{$2>3>1>4$} \\
\hline & & & \begin{tabular}{|c|} 
Get along well with part of \\
the classmates only
\end{tabular} & & & \multicolumn{4}{|c|}{$2>3>4>1$} & \multicolumn{4}{|c|}{$2 、 4>3>1$} \\
\hline & & & Isolated & & & \multicolumn{4}{|c|}{$2>4>1>3$} & \multicolumn{4}{|c|}{$2>4>3>1$} \\
\hline & & & Excellent & & & \multicolumn{4}{|c|}{$2>3>4>1$} & & $2>4$ & & \\
\hline & & & Good & & & & $2>3$ & & & & $2>4$ & & \\
\hline & & $\begin{array}{c}\text { School } \\
\text { achievement }\end{array}$ & Fair & & & & $2>3$ & & & & $2>4$ & & \\
\hline & & & Poor & & & & $2>4$ & & & & $2>4$ & & \\
\hline & & & Unqualified & & & & $2>4$ & & & & $2>4$ & $3>1$ & \\
\hline & & & $\begin{array}{l}\text { Both parents (natural } \\
\text { father/mother) }\end{array}$ & & & & $2>4$ & & & & $2>4$ & & \\
\hline & & Live with Whom & Mother or father only & & & & $2>3$ & & & & $2>4$ & & \\
\hline & & & Both grand-parents & & & & $2>1$ & & & & $2>3$ & & \\
\hline & & & Others & & & & $2>3$ & & & & $4>2$ & & \\
\hline & Family Structure & & N/A & & & & $2>1$ & & & & $2>3$ & & \\
\hline & & & 1 & & & & $2>3$ & & & & $2>4$ & & \\
\hline $\begin{array}{l}\text { Family } \\
\text { Background }\end{array}$ & & $\begin{array}{l}\text { Number of } \\
\text { Siblings }\end{array}$ & 2 & & & & $2>3$ & & & & $2>4$ & & \\
\hline Variables & & & 3 & & & & $2>4$ & $3>1$ & & & $2>4$ & & \\
\hline & & & More than 4 & & & & $2>3$ & & & & $2>3$ & & \\
\hline & & & Extremely unharmonious & & & & $2>3$ & & & & $2>4$ & & \\
\hline & & & Unharmonious & & & & $2>3$ & $1>4$ & & & $2>3$ & & \\
\hline & Harmonious & Parents' Marital & Fair & & & & $2>3$ & $4>1$ & & & $2>4$ & & \\
\hline & & & Harmonious & & & & $2>3$ & & & & $2>4$ & & \\
\hline & & & Extremely harmonious & & & & $2>3$ & & & & $2>4$ & & \\
\hline
\end{tabular}




\begin{tabular}{|c|c|c|c|c|c|c|}
\hline & & & Extremely unharmonious & $1>2$ & $2>1>4>3$ & $3>4>1=2$ \\
\hline & & & Unharmonious & $2>1$ & $2>3>4>1$ & $2>4>3>1$ \\
\hline & & $\begin{array}{l}\text { Affection for } \\
\text { Father }\end{array}$ & Fair & $1>2$ & $2>4>3>1$ & $2>4>3>1$ \\
\hline & & & Harmonious & $1>2$ & $2>3>4>1$ & $2>3=4>1$ \\
\hline & & & Extremely harmonious & $1>2$ & $2>3=4>1$ & $2>4>3>1$ \\
\hline & & & Extremely unharmonious & $1>2$ & $2>1=4>3$ & $4>2>3>1$ \\
\hline & & & Unharmonious & $2>1$ & $2>3>1>4$ & $2>1>3>4$ \\
\hline & & Affection for & Fair & $1>2$ & $2>3>4>1$ & $2>4>3>1$ \\
\hline & & & Harmonious & $1>2$ & $2>3>4>1$ & $2>4>3>1$ \\
\hline & & & Extremely harmonious & $1>2$ & $2>3>4>1$ & $2>4>3>1$ \\
\hline & & & Open and democratic & $1>2$ & $2>3>4>1$ & $2>4>3>1$ \\
\hline & Parents' Ed & cating Methods & Tyrannical and authorative & $2>1$ & $2>4>3>1$ & $2>4>3>1$ \\
\hline & & & Cold and laissez-faire & $1>2$ & $2>1>4>3$ & $1=4>2>3$ \\
\hline & & & High & $1>2$ & $2>3>4>1$ & $2>3=4>1$ \\
\hline & Parents' Socio & economic Position & Medium & $1>2$ & $2>3=4>1$ & $2>4>1>3$ \\
\hline & & & Low & $1>2$ & $2>4>3>1$ & $2>4>3>1$ \\
\hline & Dublio & Hot & Public & $1>2$ & $2>3>4>1$ & $2>4>3>1$ \\
\hline & Public/p & vate schools & Private & $1>2$ & $2>3>4>1$ & $2>4>3>1$ \\
\hline & & & Small & $1>2$ & $2>4>3>1$ & $2>4>3>1$ \\
\hline & Sch & ol Scale & Medium & $1>2$ & $2>4>1>3$ & $2>4>1>3$ \\
\hline & & & Large & $1>2$ & $2>3>4>1$ & $2>3>4>1$ \\
\hline & & & Under $10 \%$ & $1>2$ & $2>3>4>1$ & $2>3>1>4$ \\
\hline & & $\begin{array}{c}\text { Students' } \\
\text { identification with }\end{array}$ & About $25 \%$ & $1>2$ & $2>4>1>3$ & $4>2>1>3$ \\
\hline School & & homeroom & About $40 \%$ & $2>1$ & $2>3>4>1$ & $2>4>3>1$ \\
\hline Background & & teacher's care for & About $60 \%$ & $1>2$ & $2>4>3>1$ & $2>4>3>1$ \\
\hline Variables & & their learning & About $75 \%$ & $1>2$ & $2>3=4>1$ & $2>4>3>1$ \\
\hline & teacher's & & Above $90 \%$ & $1>2$ & $2>3>4>1$ & $2>4>3>1$ \\
\hline & educating & & $10 \%$ & $1=2$ & $2>4>3>1$ & $2>3>1=4$ \\
\hline & methods & $\begin{array}{c}\text { Students' } \\
\text { identification with }\end{array}$ & $25 \%$ & $1>2$ & $2>4>3>1$ & $2>4>1>3$ \\
\hline & & $\begin{array}{l}\text { Tdemeroom } \\
\text { homern }\end{array}$ & $40 \%$ & $1>2$ & $2>3>4>1$ & $2>4>3>1$ \\
\hline & & teacher's care for & $60 \%$ & $1>2$ & $2>3>4>1$ & $2>4>3>1$ \\
\hline & & their living & $75 \%$ & $1>2$ & $2>3>4>1$ & $2>3>4>1$ \\
\hline & & & $90 \%$ & $1>2$ & $2>3>4>1$ & $2>4>3>1$ \\
\hline
\end{tabular}




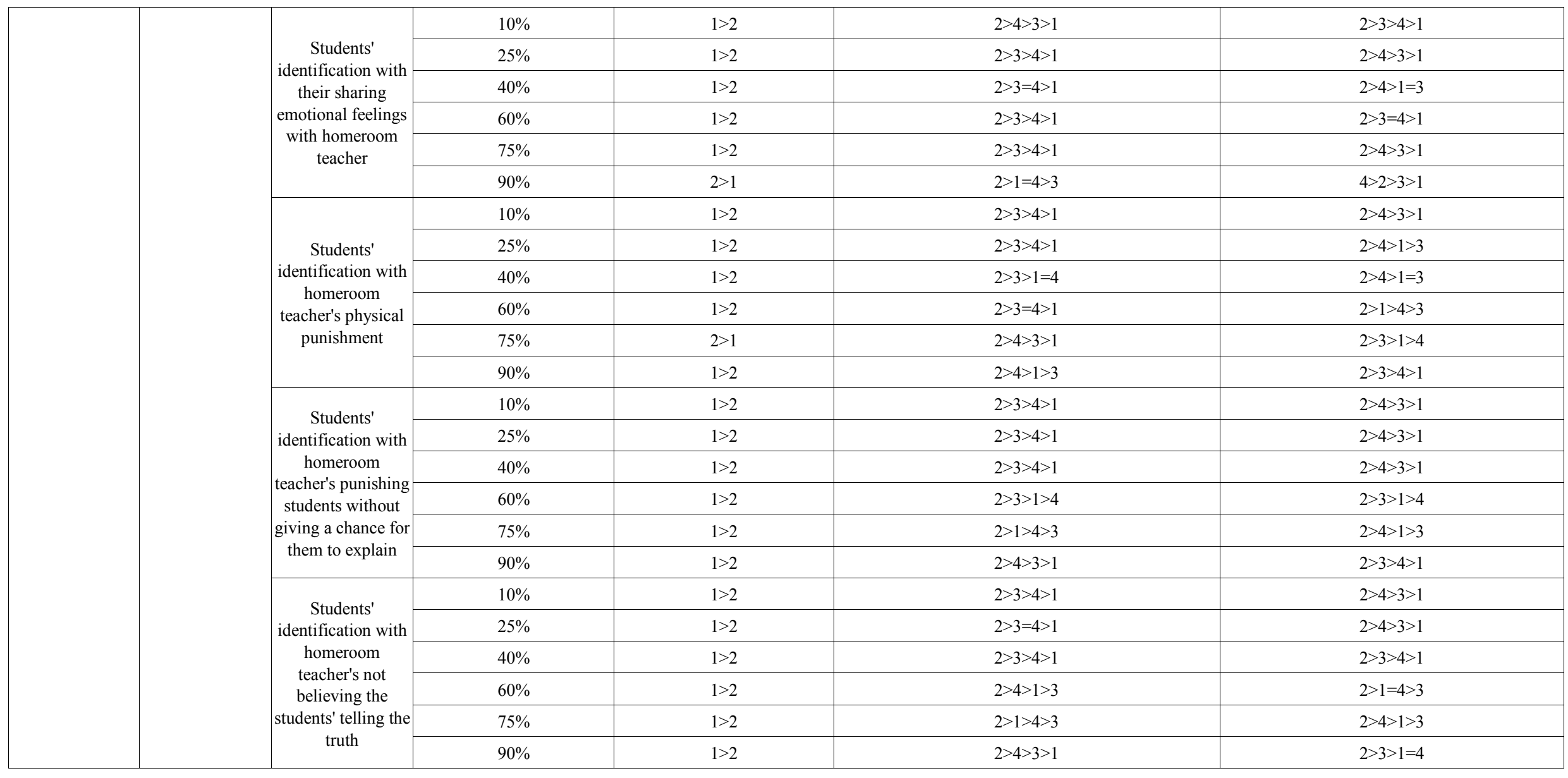


Table 7. Comprehensive Summary of Variance Analysis of School Bullying Behavior Results for Students in Students in Junior High Schools in Southern Taiwan Cities

\begin{tabular}{|c|c|c|c|c|c|c|c|c|c|c|c|c|c|}
\hline & & & \multirow[b]{2}{*}{ Full Scale } & \multirow{2}{*}{$\begin{array}{l}\text { Bullying } \\
\text { Behaviors }\end{array}$} & \multicolumn{4}{|c|}{ Bullying Behaviors } & \multirow{2}{*}{$\begin{array}{l}\text { Bullied } \\
\text { Behaviors }\end{array}$} & \multicolumn{4}{|c|}{ Bullied Behaviors } \\
\hline & & & & & Private Bullying & $\begin{array}{l}\text { Mocking } \\
\text { Bullying }\end{array}$ & Bodily Bullying & $\begin{array}{c}\text { United } \\
\text { Bullying }\end{array}$ & & $\begin{array}{l}\text { Private } \\
\text { Bullied }\end{array}$ & $\begin{array}{l}\text { Mocking } \\
\text { Bullied }\end{array}$ & $\begin{array}{l}\text { Bodily } \\
\text { Bullied }\end{array}$ & $\begin{array}{l}\text { United } \\
\text { Bullied }\end{array}$ \\
\hline \multirow{4}{*}{$\begin{array}{l}\text { Personal } \\
\text { Background } \\
\text { Variables }\end{array}$} & & Grade & & & & & Grade $9>7$ & & & & & & \\
\hline & & Gender & $\mathrm{M}>\mathrm{F}$ & $\mathrm{M}>\mathrm{F}$ & $\mathrm{M}>\mathrm{F}$ & $\mathrm{M}>\mathrm{F}$ & $\mathrm{M}>\mathrm{F}$ & $\mathrm{M}>\mathrm{F}$ & $\mathrm{M}>\mathrm{F}$ & $\mathrm{M}>\mathrm{F}$ & $\mathrm{M}>\mathrm{F}$ & $\mathrm{M}>\mathrm{F}$ & \\
\hline & & $\begin{array}{c}\text { Human } \\
\text { Relationship }\end{array}$ & $\begin{array}{l}\mathrm{P}>\mathrm{M} \\
\mathrm{I}>\mathrm{M} \\
\mathrm{I}>\mathrm{PI}>\mathrm{P}\end{array}$ & $\begin{array}{l}\mathrm{P}>\mathrm{M} \\
\mathrm{I}>\mathrm{M}\end{array}$ & $\begin{array}{l}\mathrm{I}>\mathrm{M} \\
\mathrm{I}>\mathrm{P}\end{array}$ & (0) & (0) & $\begin{array}{l}\mathrm{P}>\mathrm{M} \\
\mathrm{I}>\mathrm{M}\end{array}$ & $\begin{array}{l}\mathrm{P}>\mathrm{M} \\
\mathrm{I}>\mathrm{M} \\
\mathrm{I}>\mathrm{P}\end{array}$ & $\begin{array}{l}\mathrm{P}>\mathrm{M} \\
\mathrm{I}>\mathrm{M} \\
\mathrm{I}>\mathrm{P}\end{array}$ & $\begin{array}{l}\mathrm{P}>\mathrm{M} \\
\mathrm{I}>\mathrm{M} \\
\mathrm{I}>\mathrm{P}\end{array}$ & $\begin{array}{l}\mathrm{P}>\mathrm{M} \\
\mathrm{I}>\mathrm{M} \\
\mathrm{I}>\mathrm{P}\end{array}$ & $\begin{array}{l}\mathrm{P}>\mathrm{M} \\
\mathrm{I}>\mathrm{M} \\
\mathrm{I}>\mathrm{P}\end{array}$ \\
\hline & & $\begin{array}{c}\text { School } \\
\text { achievement }\end{array}$ & () & \begin{tabular}{|c|} 
Unqualified $>$ \\
Excellent \\
Unqualified $>$ Good \\
Unqualified $>$ Fair
\end{tabular} & & $\begin{array}{c}\text { Unqualified }> \\
\text { Excellent } \\
\text { Unqualified }> \\
\text { Good } \\
\text { Unqualified }> \\
\text { Fair } \\
\end{array}$ & & $\begin{array}{c}\text { Unqualified> } \\
\text { Excellent } \\
\text { Unqualified > } \\
\text { Good }\end{array}$ & & & & & \\
\hline \multirow{7}{*}{$\begin{array}{c}\text { Family } \\
\text { Background } \\
\text { Variables }\end{array}$} & $\begin{array}{l}\text { Number of } \\
\text { Siblings }\end{array}$ & $\begin{array}{l}\text { Number of } \\
\text { Siblings }\end{array}$ & $\begin{array}{l}\text { Single> Together } \\
\text { Others }>\text { Together }\end{array}$ & $\begin{array}{l}\text { Single }>\text { Together } \\
\text { Others }>\text { Together }\end{array}$ & $\begin{array}{l}\text { Single }>\text { Together } \\
\text { Others }>\text { Together }\end{array}$ & Single $>$ Together & & (0) & () & \begin{tabular}{|c|} 
Single> \\
Together
\end{tabular} & & & $\begin{array}{l}\text { Single> } \\
\text { Together }\end{array}$ \\
\hline & $\begin{array}{c}\text { Number of } \\
\text { Siblings }\end{array}$ & $\begin{array}{l}\text { Number of } \\
\text { Siblings }\end{array}$ & $\mathrm{N} / \mathrm{A}>2$ & $\mathrm{~N} / \mathrm{A}>2$ & $\mathrm{~N} / \mathrm{A}>1 \mathrm{~N} / \mathrm{A}>2$ & & & () & $\mathrm{N} / \mathrm{A}>2$ & $\begin{array}{l}\mathrm{N} / \mathrm{A}>1 \\
\mathrm{~N} / \mathrm{A}>2\end{array}$ & & $\begin{array}{l}\text { N/A }>1 \\
\text { N/A }>2\end{array}$ & \\
\hline & \multirow{3}{*}{$\begin{array}{l}\text { Harmonious } \\
\text { Degree }\end{array}$} & $\begin{array}{c}\text { Parents' Marital } \\
\text { Status }\end{array}$ & \begin{tabular}{|c|} 
Unharmonious $>$ \\
Harmonious \\
Unharmonious \\
$>$ Extremely \\
Harmonious \\
Fair $>$ Extremely \\
Harmonious \\
\end{tabular} & \begin{tabular}{|c|} 
Unharmonious $>$ \\
Extremely \\
Harmonious \\
Fair $>$ Harmonious \\
Fair $>$ Extremely \\
Harmonious
\end{tabular} & () & $\begin{array}{c}\text { Unharmonious }> \\
\text { Extremely } \\
\text { Harmonious } \\
\text { Fair }>\text { Extremely } \\
\text { Harmonious }\end{array}$ & $\begin{array}{c}\text { Unharmonious }> \\
\text { Harmonious } \\
\text { Unharmonious }> \\
\text { Extremely } \\
\text { Harmonious } \\
\text { Fair }>\text { Extremely } \\
\text { Harmonious } \\
\end{array}$ & $\begin{array}{c}\text { Fair> } \\
\text { Extremely } \\
\text { Harmonious }\end{array}$ & $\begin{array}{c}\text { N/A > } \\
\text { Extremely } \\
\text { Harmonious }\end{array}$ & $\begin{array}{c}\text { N/A }> \\
\text { Extremely } \\
\text { Harmonious }\end{array}$ & & $\begin{array}{c}\text { N/A }> \\
\text { Extremely } \\
\text { Harmonious }\end{array}$ & $\begin{array}{c}\text { N/A }> \\
\text { Extremely } \\
\text { Harmonious }\end{array}$ \\
\hline & & $\begin{array}{l}\text { Affection for } \\
\text { Father }\end{array}$ & () & $\begin{array}{c}\text { Extremely } \\
\text { Unharmonious } \\
>\text { Harmonious } \\
\text { Extremely } \\
\text { Unharmonious } \\
>\text { Extremely } \\
\text { Harmonious }\end{array}$ & $\begin{array}{c}\text { Extremely } \\
\text { Unharmonious } \\
>\text { Unharmonious, } \\
\text { Fair, Harmonious, } \\
\text { Extremely } \\
\text { Harmonious }\end{array}$ & & $\begin{array}{c}\text { N/A>Extremely } \\
\text { N/A }>\text { Extremely } \\
\text { Harmonious }\end{array}$ & (0) & $\begin{array}{c}\text { N/A }> \\
\text { Extremely } \\
\text { Harmonious } \\
\text { N/A }> \\
\text { Harmonious }\end{array}$ & (0) & $\begin{array}{c}\text { N/A }> \\
\text { Extremely } \\
\text { Harmonious } \\
\text { N/A }> \\
\text { Harmonious }\end{array}$ & (0) & \\
\hline & & $\begin{array}{l}\text { Affection for } \\
\text { Mother }\end{array}$ & () & () & $\begin{array}{c}\text { Extremely } \\
\text { Unharmonious } \\
>\text { Extremely } \\
\text { Harmonious }\end{array}$ & $\begin{array}{c}\text { Fair }>\text { Extremely } \\
\text { Harmonious }\end{array}$ & & () & (0) & $\begin{array}{c}\mathrm{N} / \mathrm{A}> \\
\text { Harmonious }\end{array}$ & () & & $\begin{array}{c}\mathrm{N} / \mathrm{A}> \\
\text { Harmonious }\end{array}$ \\
\hline & & $\begin{array}{l}\text { Parents' } \\
\text { Educating } \\
\text { Methods }\end{array}$ & $\begin{array}{c}\text { Laissez } \\
\text { faire }>\text { Democratic }\end{array}$ & $\begin{array}{l}\text { Laissez-faire> } \\
\text { Democratic }\end{array}$ & \begin{tabular}{|c|} 
Laissez \\
faire>Democratic \\
Laissez-faire> \\
Tyrannic \\
\end{tabular} & & & (0) & $\begin{array}{l}\mathrm{T}>\mathrm{D} \\
\mathrm{L}>\mathrm{D}\end{array}$ & $\begin{array}{l}\mathrm{T}>\mathrm{D} \\
\mathrm{L}>\mathrm{T}\end{array}$ & () & () & $\begin{array}{l}T>D \\
L>D\end{array}$ \\
\hline & & $\begin{array}{l}\text { Parents' Socio } \\
\text { economic } \\
\text { Position }\end{array}$ & & & & (0) & & & & & & & \\
\hline
\end{tabular}




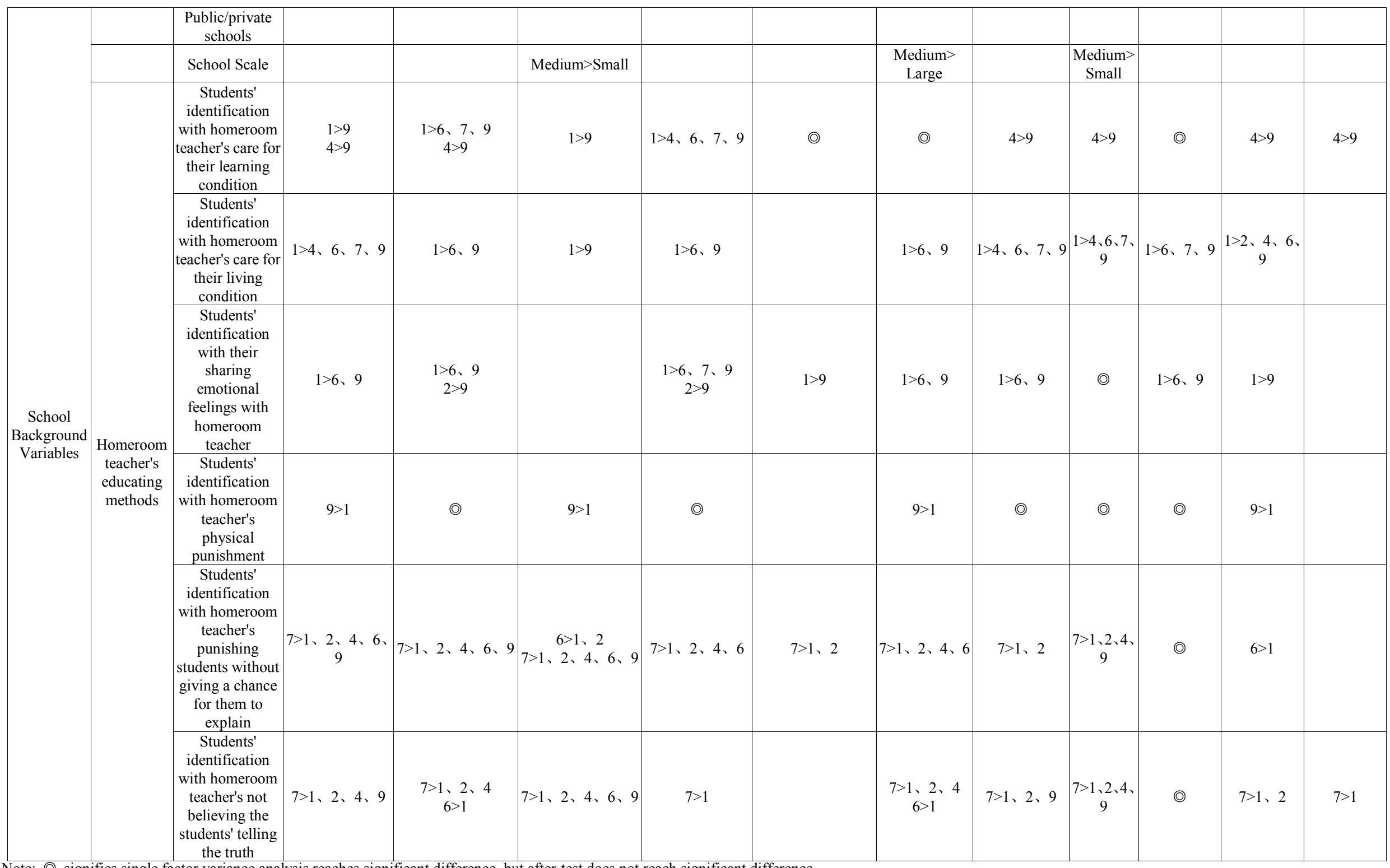

Note: () signifies single factor variance analysis reaches significant difference, but after-test does not reach significant difference. 
Table 8. Multiple Regression Analysis of School Bullying Behaviors

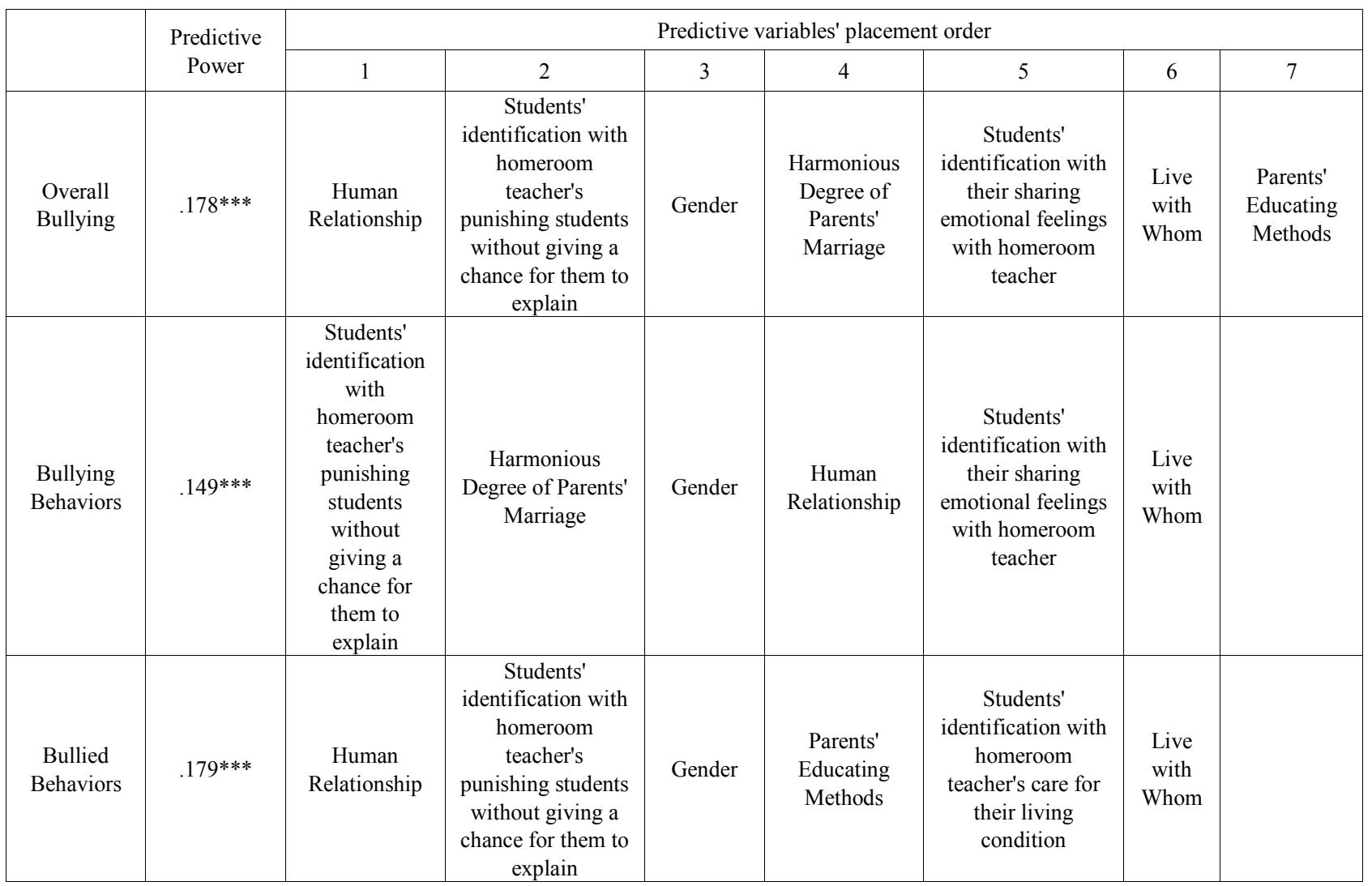

$* * *$ refers to $\mathrm{P}<.001$

\section{(III). Prediction that Influence Factors of School Bullying Behaviors}

In Table 8, we integrate the prediction that influences factors of school bullying behaviors of students in junior high schools in Southern Taiwan cities.

\section{Research Conclusions and Related Suggestions}

To respond to results and recount of questions to be answered, we deducted the primary conclusions for bullying behaviors of students in junior high schools in Southern Taiwan cities.

\section{(I). The Current Condition and Distribution of School Bullying Behaviors by Students in Junior High Schools in Southern Taiwan Cities}

The research results are illustrated as below:

1. We should face up to school bullying behaviors of students in junior high schools in Southern Taiwan cities

According to the data obtained by this research, we analyzed the overall bullying behaviors of students in junior high schools in Southern Taiwan cities, and found the mean of overall bullying behaviors is 1.23 , and the percentage is $13.45 \%$. As a whole, the condition of bullying behaviors of students in junior high schools in Southern Taiwan cities is not serious, but such behaviors still exist and should be faced up to for solutions in order to further reduce the occurrence rate.

2. Regarding bullying behaviors of students in junior high schools in Southern Taiwan cities, the most serious bullying behaviors (matching extent over 90\%) are more than the less serious bullying behaviors (matching extent 75\%), which is worthy of value and seeking for improvement.

The mean of bullying behaviors of students in junior high schools in Southern Taiwan cities is 1.25 , the percentage is about $13.75 \%$, and the match extent by order is: the match extent under $10 \%$ is $85.65 \%, 25 \%$ is $8.70 \%, 60 \%$ is $1.27 \%$, $75 \%$ is $0.66 \%$, and over $90 \%$ is $0.86 \%$, all The match extent under $10 \%$ occupies the largest proportion, $75 \%$ the smallest proportion, and above $90 \%$ is more than $75 \%$. In addition, though the overall bullying behaviors are not serious, few serious bullying events increase instead of declining, which is worthy of relative parents, teachers, and educational units to understand and work for solutions.

3. Regarding bullied behaviors of students in junior high schools in Southern Taiwan cities, the most serious bullied behaviors (matching extent over 90\%) are more than the less serious bullied behaviors (matching extent 75\%), which is worthy of value and seeking for improvement.

The mean of bullied behaviors of students in junior high schools in Southern Taiwan cities is 1.21 , the percentage is about $13.15 \%$, and the match extent by order is: the match 
extent under $10 \%$ is $88.95 \%, 25 \%$ is $6.00 \%, 40 \%$ is $2.33 \%$, $60 \%$ is $1.16 \%, 75 \%$ is 0.58 , and over $90 \%$ is $0.97 \%$, all The match extent under $10 \%$ occupies the largest proportion, $75 \%$ the smallest proportion, and above $90 \%$ is more than $75 \%$. In addition, though the overall bullied behaviors are not serious, few serious bullied events increase instead of declining, which is worthy of relative parents, teachers, and educational units to understand and work for solutions.

4. Overall bullied behaviors of students in junior high schools in Southern Taiwan cities perform differently in each construct and dimension, so the relative units and personnel should try to understand and seek for the solutions.

On the basis of the results from descriptive statistics of each construct and dimension of overall bullied behaviors of students in junior high schools in Southern Taiwan cities, it is found that:

1. The severity of bullying behaviors in sequence are mocking bullying, bodily bullying, united bullying, and private bullying. Among them, mocking bullying is the most serious, and private bullying is the most slight.

2. The severity of bullied behaviors in sequence is mocking bullied, united bullied, bodily bullied, and private bullied. Among them, mocking bullied is the most serious, and private bullied is the most slight.

\section{(II). Difference Exists in the Personal Background Variables of Students in Junior High Schools in Southern Taiwan Cities and School Bullying Behaviors}

On the basis of the research results, it is found that except grade, the overall school bullying behaviors of students with different personal backgrounds in junior high schools in Southern Taiwan cities reach significant difference.

1. Regarding grade, except that Grade 9 students' bodily bullying is more serious than Grade-7 students, and reaches significant difference, the remaining do not reach significant difference.

2. On the whole, boys' school bullying behaviors are more serious than girls', reaching significant difference. As for each aspect of bullying and bullied (except united bullied), boys' condition is more serious than girls' as well.

3 . The overall school bullying behaviors of students with different human relationships are more serious than those of students with isolated relationship, showing those with poor human relationship have school bullying behaviors more serious than those with good human relationship.

4. The overall school bullying behaviors of students with different schoolwork achievement do not reach significant difference, but are more serious than those with other schoolwork achievements. The bullied behaviors do not reach significant difference.

\section{(III). Difference Exists in Different Family Backgrounds of Students in Junior High Schools in Southern Taiwan Cities and School Bullying Behaviors}

1. In regard of overall, partial constructs and dimensions of school bullying behaviors, those living with their father and mother perform the slightest, reaching significant difference.

2. Those without siblings perform the most seriously in respect with school bullying behaviors, bullying behaviors, and bullied behaviors, reaching significant difference.

3. The more unharmonious marriage of the parents, the more seriously students perform in respect with school bullying behaviors, bullying behaviors, and bullied behaviors, reaching significant difference.

4. Those who have poor affection for their father do not have overall school bullying behaviors reaching significant difference. However, in the remaining part of constructs and dimensions, their school bullying behaviors are more serious, reaching significant difference.

5. Those who have better affection for their mother do not have overall school bullying behaviors reaching significant difference. However, in the remaining part of constructs and dimensions, their school bullying behaviors are less serious, reaching significant difference.

6. In respect with overall school bullying behaviors, and the remaining part of constructs and dimensions, those whose parents' educational methods are open and democratic perform the most mildly, reaching significant difference.

7. In respect with overall school bullying behaviors, and the remaining part of constructs and dimensions, those whose parents' socioeconomic positions are different do not reach significant difference.

\section{(IV). Difference Exists in Different School Backgrounds of Students in Junior High Schools in Southern Taiwan Cities and School Bullying Behaviors}

1. In respect with overall school bullying behaviors, and the remaining constructs and dimensions, the public and private schools do not reach significant difference.

2. In respect with school bullying behaviors, different school scales do not reach significant difference.

3. In respect with overall school bullying behaviors, and the remaining constructs and dimensions, the more the students identify with homeroom teacher's care for their learning condition, the more mildly they will perform, and reach significant difference.

4. In respect with overall school bullying behaviors, and the remaining constructs and dimensions, the more the students identify with homeroom teacher's care for their living condition, the more mildly they will perform, and reach significant difference.

5. In respect with overall school bullying behaviors, and the remaining constructs and dimensions, the more the students identify with homeroom teacher's sharing emotional feelings, the more mildly they will perform, and reach significant difference.

6. In respect with overall school bullying behaviors, and the remaining constructs and dimensions, the more the students identify with homeroom teacher's physical punishment for the students, the most seriously they will perform, and reach significant difference. 
7. In respect with overall school bullying behaviors, and the remaining constructs and dimensions, the more the students identify with homeroom teacher's punishing students without giving a chance for explanation, the more seriously they will perform, and reach significant difference.

8. In respect with overall school bullying behaviors, and the remaining constructs and dimensions, the more the students identify with homeroom teacher's not believing students' telling the truth, the more seriously they will perform, and reach significant difference.

\section{(V). Among the Factors that Influence School Bullying Behaviors of Students in Junior High School Students in Southern Taiwan Cities, Seven have Predictive Power for School Bullying Behaviors}

According to the research results, it is found that in respect of "Human Relationship", "identification extent with homeroom teacher punishes students without giving a chance for them to explain", "gender", "parents' marriage harmony degree", "Students' identification with their sharing emotional feelings with homeroom teacher", "Living with whom", and "Parents' Educating Methods", students' performance can predict the occurrence of their overall school bullying behaviors.

\section{(VI). The Overall School Bullying Behaviors, Bullying} Behaviors, and Bullied Behaviors of Students in Junior High School Students in Southern Taiwan Cities Reach Significantly Positive Correlation

Regarding the overall school bullying behaviors, bullying behaviors, and bullied behaviors of students in junior high school students in southern Taiwan cities, after analyzing, it is found that they have significantly positive correlation. That is, as long as students perform seriously in one item, they will perform more seriously in the other items.

(VII). The Dimensions of Bullying Behaviors, and Bullied Behaviors of Students in Junior High School Students in Southern Taiwan Cities Reach Significantly Positive Correlation

Regarding the dimensions of bullying behaviors (private bullying, mocking bullying, bodily bullying, and united bullying), and bullied behaviors (private bullied. mocking bullied, bodily bullied, and united bullied) of students in junior high school students in southern Taiwan cities, after analyzing, it is found that they have significantly positive correlation. That is, as long as students perform seriously in one item, they will perform more seriously in the other items.

This research conducted investigation targeting at the school bullying behaviors of students in junior high schools in Southern Taiwan cities. In accordance with the previously mentioned findings and conclusions, we proposed the following recommendations, wishing to help improve the school bullying behaviors of students in junior high schools in Southern Taiwan cities.

\section{(I). School Strengthens the Mentoring Mechanism and Seek for Resource Assistance}

Upon facing school bullying behaviors, in addition to timely treatment, school administration personnel should focus on the mentoring for the bully and the bullied. Therefore, school administration personnel should strengthen the mentoring mechanism, and set up mentoring resource network, so that when the mentoring teachers cannot handle, they can ask for help from more professional resources of mentoring to help change the bully's behaviors and assist the bullied to recover from the harm, reducing school bullying behaviors to the least.

\section{(II). Propagate and Clear Anti-bullying Appeal Channels}

Some bullied students are stuck to the difficulty without any help because of the peer pressure, introvert personality, or being threatened by the bully. However, this will only encourage the bully's behaviors, leading to unmanageable school bullying behaviors. Therefore, the administration personnel should stress on propagate anti-bullying appeal channels, so that the bullied students can appeal, and the bully can be deferred by such channels.

\section{(III). School's Administration Personnel Should Positively Face up to Treatment of School Bullying Behaviors}

When the school administration personnel face school bullying behavior, they should try to understand and treat it positively, not just comfort the bullied students negatively and appease the bully, since this equals to encouraging school bullying behaviors, which will make bullying behaviors become even more rampant. In encountering the school bullying behaviors, school administration personnel should positively understand the causes of the bullying event. There should be a mechanism for the bully and the bullied to clarify the responsibility and receive tracking and mentoring. In this way, the bully can take the responsibility, and the bullied can receive good consultancy to recover from physical and mental harm.

\section{(IV). Consolidate Gender Equality Teaching Materials, Integrate Gender Equality into Teaching and Promote Related Propaganda}

Gender reaches significant difference in affecting school bullying behaviors of students in junior high schools in Southern Taiwan cities, so we suggest that school can develop gender equality related programs. School teachers are personnel who "implement the program", and the action research may include innovation of program's content, application of teaching methods, teacher-student interaction, and etc. in order to benefit the students' learning effectiveness (Wang \& Huang, 2014)[56]. By means of school or teachers writing and editing gender equality teaching materials, gender equality can be integrated into teaching each semester or in opportunity education, so that we can raise students' awareness of gender equality as the 
point, cultivate concept of gender equality in classroom as the line, and construct gender equality in school as the plane. It is believed that through teaching material design, teaching integration, school promotion, we can raise consciousness of all students in school to respect the opposite sex, which may decrease school bullying caused by gender difference.

\section{(V). Hold More Students' Educational Camps}

Students' human relationship reaches significant difference that influences school bullying behaviors of students in junior high schools in Southern Taiwan cities, so we recommend school to hold students' educational camp to cultivate students' good human relationship. When students have good human relationship, it will be easier for them to establish and maintain friendship. When the individual encounters difficulty in human relationship, it will be hard for him/her to establish friendship, and easy to bully others or get bullied. As a result, quality educational camp will be helpful for students to break through limitation of class peers and expand and set up quality human relationship, so that school bullying behaviors can be decreased.

\section{(VI). Made up Little Group in Class}

Human relationship and school work achievement reach significant difference that influences school bullying behaviors of students in junior high schools in Southern Taiwan cities. As the saying that goes, "He that touches pitch shall be defiled", homeroom teacher cam cultivate students' human relationship through class little group. By making use of their valuing peers at this stage, teacher can encourage them to learn from others, which is believed that it can reduce occurrence of school bullying behaviors. In addition, the teacher can consider to use reading therapy program; by means of class shared reading program, students' awareness of anti-bullying can be raised.

\section{(VII). Hold Parent-teacher Meetings to Propagate Family Education}

Family structure, family harmonious degree, and parents' educating methods achieve significant difference that influences school bullying behaviors of students in junior high schools in Southern Taiwan cities, so we suggest school hold parent-teacher meetings and propagate the importance of family education. Through this way, parents can understand family's importance in child's growth. In addition, it is expected that parents can have good marital, parent-child, and sibling relationship, and use correct methods to education their children. In regard of the family background factor and home background factor that influence school bullying behaviors, with school's promotion and parents' coordination, children's deviation behaviors and school bulling behaviors will be reduced.

\section{(VIII). Enhance Parent-teacher Cooperation, and Carry out Home Visit}

Family structure, family harmonious degree, and parents' educating methods reaches significant difference that influences school bullying behaviors of students in junior high schools in Southern Taiwan cities. As a result, homeroom teacher can implement family visit. On one hand, they can mentor students via parent-teacher cooperation, understand their family situation to support them when necessary, and propagate the importance of family education by providing correct information. Consequently, strengthening parent-teacher cooperation, and implementing family visit can diminish students' deviation behaviors effectively, and further diminish school bullying behaviors.

(IX). Increase Homeroom Teacher's Educating Methods, and Raise Chances for Him/Her to Study or Receive Training, Open Relative Courses and Encourage Teachers to Participate

Home-room teacher's educating method reaches significant difference that influences school bullying behaviors of students in junior high schools in Southern Taiwan cities. Therefore, the educational authority or school can hold related study \& training on homeroom teacher's class operation. Teacher education institutes open credit classes on teachers' educational methods further in-service teachers and future teachers to study and receive training. In addition, schools can cultivate seed teachers for class operation, strengthen knowledge and skills of the homeroom teacher, making every student show their active and lively appearance, raise their sense of group belonging to class and school, so that all can work together to accomplish the overall goals and create a class situation without sense of isolation and squeezing one another. With such measures, we can enhance homeroom teacher's correct concepts and skills, and we expect that, through homeroom teacher's care for the students or share moods with them, we may cultivate quality teacher-student interaction and mutual trust in order to reduce occurrence of. Or, if school bullying behaviors have taken place, through quality teacher-student interaction and mutual trust, homeroom teacher can detect the sign of school bullying behaviors and take measures/actions to prevent them from happening.

\section{(X). Homeroom Teacher Should Teach and Control Students Positively, Care for the Students to Cultivate Good Teacher-student Interaction}

Home-room teacher's educating method reaches significant difference that influences school bullying behaviors of students in junior high schools in Southern Taiwan cities. Therefore, if homeroom teacher can operate class positively, occurrence of students' deviation behaviors can be restricted. As we discovered, regarding students as his/her own children, paying more attention to them, and students will keep what teacher inculcates in their mind and even put it into practice. Consequently, developing good teacher-student interaction, together with students' willingness to share their moods and feelings and what takes place in daily life with the teacher, the homeroom teacher can have a clear idea about interaction among students and therefore can prevent bullying problem from occurring. In 
the meantime, through $6 \mathrm{E}$ innovative teaching strategies, the teacher can integrate formal programs, informal programs, potential programs, and so on in order to bring to a full play his/her verbal modeling, action modeling, and environmental modeling, and have parents, teacher(s), and children embody core value of moral character to set up the characteristic of campus culture with standard of moral character (Wang \& Huang, 2014)[56]. In short, for educational workers (particularly the homeroom teacher), if they can teach, manage, and care for students positively, develop good teacher-student interaction, and enhance moral character education, it is deeply believed that school bullying behaviors will decline gradually, and students will be able to learn happily on a friendly campus without bullying.

\section{REFERENCES}

[1] C. Wang, B. Berry, \& S. M. Swearer. The critical role of school climate in effective bullying prevention. Theory Into Practice, Vol, 52, No. 4, 296-302, 2013.

[2] S. Siziya, E. Rudatsikira, \& A. S. Muula. Victimization from bullying among school-attending adolescents in grades 7 to 10 in Zambia. Journal of injury and violence research, Vol. 4, No. 1, 30, 2012.

[3] J. M. Bollmer., et al. Reactions to bullying and peer victimization: Narratives, physiological arousal, and personality. Journal of Research in Personality, Vol. 40,803-828, 2006.

[4] G. Gini. Bullying as a social process: The role of group membership in students' perception of inter-group aggression at school. Journal of School Psychology, Vol.44, 51-65, 2006.

[5] M. M. Trofi, \& D. P. Farrington. Effectiveness of school-based programs to reduce bullying: A systematic and meta-analytic review. Journal of Experimental Criminology, Vol. 7, No. 1, 27-56, 2011.

[6] K. S. Berger. Update on bullying at school: Science forgotten?. Developmental review, Vol. 27, No. 1, 90-126, 2007.

[7] S. N. Georgiou, \& P. Stavrinides. Parenting at home and bullying at school. Social psychology of education, Vol. 16, No. 2, 165-179, 2013.

[8] K. E. Carlyle, \& K. J. Steinman. Demographic Differences in the Prevalence, Co - Occurrence, and Correlates of Adolescent Bullying at School. Journal of School Health, Vol. 77, No. 9, 623-629, 2007.

[9] D. Olweus, \& S. P. Limber. Bullying in school: Evaluation and dissemination of the Olweus Bullying Prevention Program. American Journal of Orthopsychiatry, Vol. 80, No. 1, 124-134, 2010.

[10] K. Rigby. Children and bullying: How parents and educators can reduce bullying at school. Blackwell Publishing, 2008.

[11] I. Rivers, V. P. Poteat,, N. Noret, \& N. Ashurst. Observing bullying at school: The mental health implications of witness status. School Psychology Quarterly, Vol. 24 , No. 4, 211, 2009.

[12] D. Bender, \& F. Lösel. Bullying at school as a predictor of delinquency, violence and other anti - social behaviour in adulthood. Criminal Behaviour and Mental Health, Vol. 21, No. 2, 99-106, 2011.

[13] G. M. Glew, M. Y. Fan, W. Katon, \& F. P. Rivara, F. P. Bullying and school safety. The Journal of pediatrics, Vol. 152, No. 1, 123-128, 2008.

[14] M. Nation, A. Vieno, D. D. Perkins, \& M. Santinello. Bullying in school and adolescent sense of empowerment: An analysis of relationships with parents, friends, and teachers. Journal of Community \& Applied Social Psychology, Vol. 18, No. 3, 211-232, 2008.

[15] R. Lund, K. K. Nielsen, D. H. Hansen, M. Kriegbaum, D. Molbo, P. Due, \& U. Christensen. Exposure to bullying at school and depression in adulthood: a study of Danish men born in 1953. The European Journal of Public Health, Vol. 19, No. 1, 111-116, 2009.

[16] K. R. Williams, \& N. G. Guerra. Prevalence and predictors of internet bullying. Journal of Adolescent Health, Vol. 41, No.6, S14-S21, 2007.

[17] P. Due, \& B. E. Holstein. Bullying victimization among 13 to 15 year old school children: results from two comparative studies in 66 countries and regions. International journal of adolescent medicine and health, Vol. 20, No. 2, 209-222, 2008.

[18] S. Allison, L. Roeger, \& N. Reinfeld-Kirkman. Does school bullying affect adult health? Population survey of health-related quality of life and past victimization. Australian and New Zealand journal of psychiatry, Vol. 43, No. 12, 1163-1170, 2009.

[19] H. Kartal, \& A. Bilgin. Bullying and school climate from the aspects of the students and teachers. Eurasian Journal of Educational Research, Vol. 36, 209-226, 2009.

[20] R. Thornberg. 'She's Weird!'-The Social Construction of Bullying in School: A Review of Qualitative Research. Children \& Society, Vol. 25, No. 4, 258-267, 2011.

[21] L. A. Beaty, \& E. B. Alexeyev. The problem of school bullies: What the research tells us. ADOLESCENCE-SAN DIEGO-, Vol. 43, No. 169, 1, 2008.

[22] D. Vanderbilt, \& M. Augustyn. Bullying and school violence. Nelson Textbook of Pediatrics, 19th ed., online, 2011.

[23] D. P. Farrington, \& M. M. Ttofi. How to reduce school bullying. Victims and Offenders, Vol. 4, No. 4, 321-326, 2009.

[24] L. Marsh, R. McGee, S. Nada-Raja, \& S. Williams. Brief report: Text bullying and traditional bullying among New Zealand secondary school students. Journal of adolescence, Vol. 33, No. 1, 237-240, 2010.

[25] J. Juvonen, \& E. F. Gross. Extending the school grounds?-Bullying experiences in cyberspace. Journal of School health, Vol. 78, No. 9, 496-505, 2008.

[26] T. Vaillancourt, V. Trinh, P. McDougall, E. Duku, E., L. Cunningham, C. Cunningham, ... \& K. Short. Optimizing population screening of bullying in school-aged children. Journal of School Violence, Vol. 9, No. 3, 233-250, 2010. 
[27] S. Lindsay, \& A. C. McPherson. Experiences of social exclusion and bullying at school among children and youth with cerebral palsy. Disability and rehabilitation, Vol. 34, No. 2, 101-109, 2012.

[28] A. Petrosino, S. Guckenburg, J. DeVoe, \& T. Hanson. What Characteristics of Bullying, Bullying Victims, and Schools Are Associated with Increased Reporting of Bullying to School Officials? Issues \& Answers. REL 2010-No. 092. Regional Educational Laboratory Northeast \& Islands, 2010.

[29] C. P. Bradshaw, \& T. E. Waasdorp. Measuring and changing a "culture of bullying.". School Psychology Review, Vol. 38, No. 3, 356-361, 2009.

[30] S. G. Ramya, \& M. L. Kulkarni. Bullying among school children: prevalence and association with common symptoms in childhood. The Indian Journal of Pediatrics, Vol. 78, No. 3, 307-310, 2011.

[31] S. M. Swearer, D. L. Espelage, T. Vaillancourt, \& S. Hymel. What can be done about school bullying? Linking research to educational practice. Educational Researcher, Vol. 39, No. 1, 38-47, 2010.

[32] C. V. Farrow, \& C. L. Fox. Gender differences in the relationships between bullying at school and unhealthy eating and shape - related attitudes and behaviours. British journal of educational psychology, Vol. 81, No. 3, 409-420, 2011.

[33] S. B. Mehta, D. Cornell, X. Fan, \& A. Gregory. Bullying climate and school engagement in ninth - grade students. Journal of school health, Vol. 83, No. 1, 45-52, 2013.

[34] F. Pergolizzi, D. Richmond, S. Macario, Z. Gan, C. Richmond, \& E. Macario. Bullying in middle schools: Results from a four-school survey. Journal of school violence, Vol. 8, No. 3, 264-279, 2009.

[35] G. Roth, Y. Kanat - Maymon, \& U. Bibi. Prevention of school bullying: The important role of autonomy - supportive teaching and internalization of pro - social values. British Journal of Educational Psychology, Vol. 81, no. 4, 654-666, 2011.

[36] S. K. Schneider, L. O'Donnell, A. Stueve, \& R. W. Coulter. Cyberbullying, school bullying, and psychological distress: A regional census of high school students. American Journal of Public Health, Vol. 102 , No. 1, 171-177, 2012.

[37] H. D. Bull., Schultze, M., \& Scheithauer, H. School-based prevention of bullying and relational aggression: The fairplayer. manual. European Journal of Developmental Science, Vol. 3, No. 3, 312-317, 2009.

[38] E. Viding, E. J. McCrory, S. J. Blakemore, \& N. Frederickson. Behavioural problems and bullying at school: can cognitive neuroscience shed new light on an old problem?. Trends in cognitive sciences, Vol. 15, No. 7, 289-291, 2011.

[39] D. Olweus. Bullying at school and later criminality: Findings from three Swedish community samples of males. Criminal behaviour and mental health, Vol. 21, No. 2, 151-156, 2011.

[40] S. R. Jimerson, S. M. Swearer, \& D. L. Espelage. Handbook of bullying in schools: An international perspective. Routledge/Taylor \& Francis Group, 2010.

[41] I. Rivers, \& N. Noret. Potential suicide ideation and its association with observing bullying at school. Journal of Adolescent Health, Vol. 53, No. 1, S32-S36, 2013.

[42] G. Atik. Assessment of school bullying in Turkey: a critical review of self-report instruments. Procedia-Social and Behavioral Sciences, Vol. 15, 3232-3238, 2011.

[43] T. A. Bosiakoh. Differential Association Theory. In Encyclopedia of the Sciences of Learning (pp. 990-992). Springer US, 2012.

[44] B. Moon, H. W. Hwang, \& J. D. McCluskey. Causes of school bullying: Empirical test of a general theory of crime, differential association theory, and general strain theory. Crime \& Delinquency, 2008

[45] T. C. Link. Differential Association Theory. The Encyclopedia of Theoretical Criminology, 2014.

[46] D. Black. (Ed.). Toward a general theory of social control: Fundamentals (Vol. 1). Academic Press, 2014.

[47] L. Rosenthal, \& S. R. Levy. Understanding women's risk for HIV infection using social dominance theory and the four bases of gendered power. Psychology of Women Quarterly, Vol. 34, No. 1, 21-35, 2010.

[48] J. Sidanius, \& F. Pratto. Social dominance theory. Handbook of Theories of Social Psychology: Volume Two, 2, 418, 2011.

[49] G. Corey. Theory and practice of group counseling. Cengage Learning, 2011.

[50] H. Elias, S. E. Krauss, \& S. A. Aishah. A review study on spiritual intelligence, adolescence and spiritual intelligence, factors that may contribute to individual differences in spiritual intelligence, and the related theories. International Journal of Psychological Studies, 2(2), p179, 2010.

[51] C. F. Garandeau, \& A. H. Cillessen. N. From indirect aggression to invisible134aggression: A conceptual view on bullying and peer group manipulation. Aggression and Violent Behavior, Vol. 11, 612-625, 2006.

[52] M. Birkett, D. L. Espelage, \& B. L. Koenig. LGB and questioning students in schools: The moderating effects of homophobic bullying and school climate on negative outcomes. Journal of youth and adolescence, Vol. 38, No. 7, 989-1000, 2009.

[53] M. Pujazon-Zazik. Bullying in School. AAP Grand Rounds, Vol. 19, No. 4, 46-47, 2008.

[54] L. Roeger, S. Allison, R. Korossy-Horwood, K A. Eckert, \& R. D. Goldney. Is a history of school bullying victimization associated with adult suicidal ideation?: a South Australian population-based observational study. The Journal of nervous and mental disease, Vol. 198, No. 10, 728-733, 2010.

[55] D. Olweus. Bullying at school: What we know and what we can do. 1993. In Karen Siris will present at a full-day workshop entitled Meeting the Requirements of the Dignity Act: New York State's Anti-Bullying and Harassment Law, on April 2, 2012, at the Holiday Inn in Saratoga Springs. For more information, go to saanys. org/events, 2013.

[56] C. H. Wang, \& G. F. Huang. The dealing strategies for campus bullying behaviors, Taiwan Education, Vol. 685, 46-49, 2014. 